\title{
Focusing economic research on the issues of sustainability and environmental protection
}

\author{
Alin ARTENe, PhD \\ Faculty of Management in Production and Transportation, \\ Politehnica University Timișoara, Romania \\ artene_alin@yahoo.com
}

\begin{abstract}
Trying to find solutions for trivalent durability (economic / financial, social and environmental issues) is becoming more and more a preoccupied concerns of many specialists. In this paper we make some references to the Romanian researchers focus on the issue of sustainable development, especially with Professor Ionel Bostan, which operates at the universities of Iasi and Suceava (RO). His work, published in several scientific journals indexed in international databases, addresses issues related to promoting natural capital, the right of future generations to a healthy environment, eco-investments, green tourism, green energy, environmental audit, economy and public health financing and then, because "People are at the forefront of sustainable development", issues related to the human factor.
\end{abstract}

Key word: sustainable development; natural capital; human capital; health and well-being; budgetary resources; financing biodiversity; control / audit of public funds.

\section{Introduction}

The issue of sustainable development is today as important as possible, in the center of which is placed the human individual. To understand what we reffer to, it is enough to recall the definition of sustainable development, that type of development focused on "meeting the needs of the present, without compromising the possibilities of future generations to meet their own needs" [1]. The features of this concept imply among others: performance / efficiency, growth, stability, living standards, equity, preserving and protecting natural resources, biodiversity and avoiding pollution. Spheres intersected / involved here, as it results from Figure $\mathbf{1}$, are the social, the economic and the

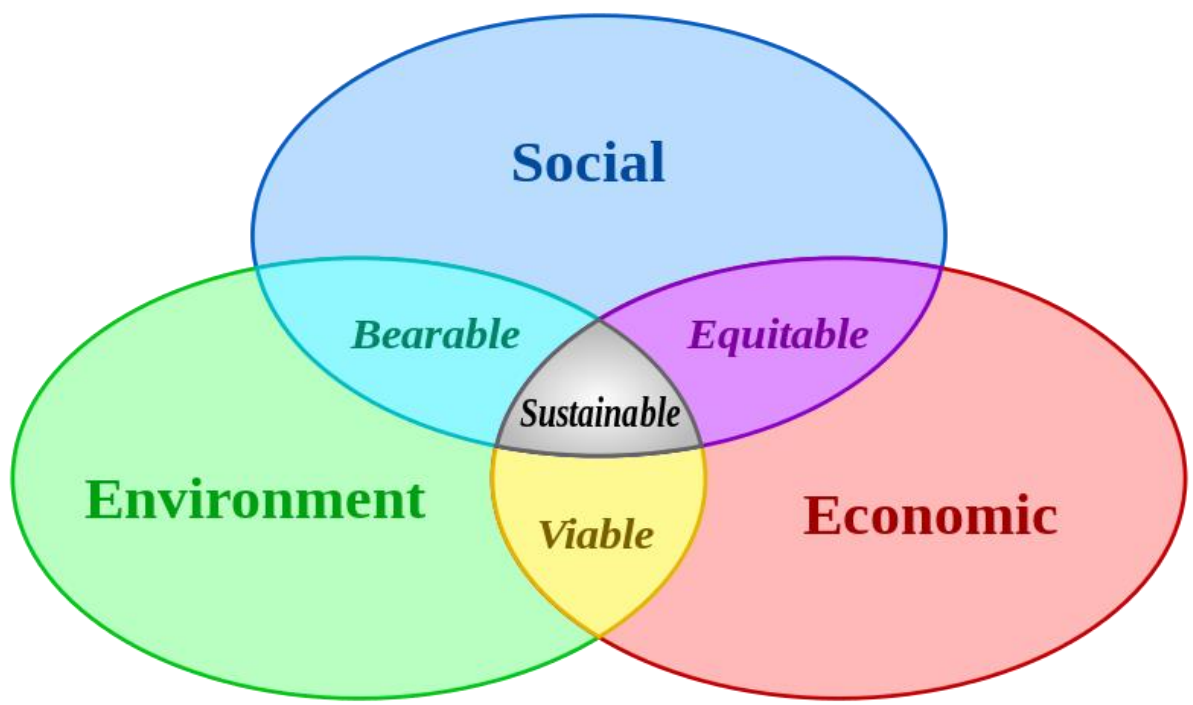

Figure 1: Sustainable development

Source: https://ro.wikipedia.org/wiki/Portal:Dezvoltare_durabilă

environmental ones. In the European context, we recall that Agenda 2030 includes 17 Sustainable Development Objectives [2]. These were also 
assumed by Romania (2015), alongside the 193 UN member states, assuming poverty and hunger to be eradicated by 2030 [3]. Other objectives regard: ensuring health and well-being, guaranteeing quality education, achieving gender equality, providing clean water and sanitation, ensuring clean and affordable energy. Obviously, there is no lack of concern for goals such as ensuring decent work, reducing inequalities within countries and from one country to another, or consumption and responsible production, all in the context of peace, justice and effective institutions.
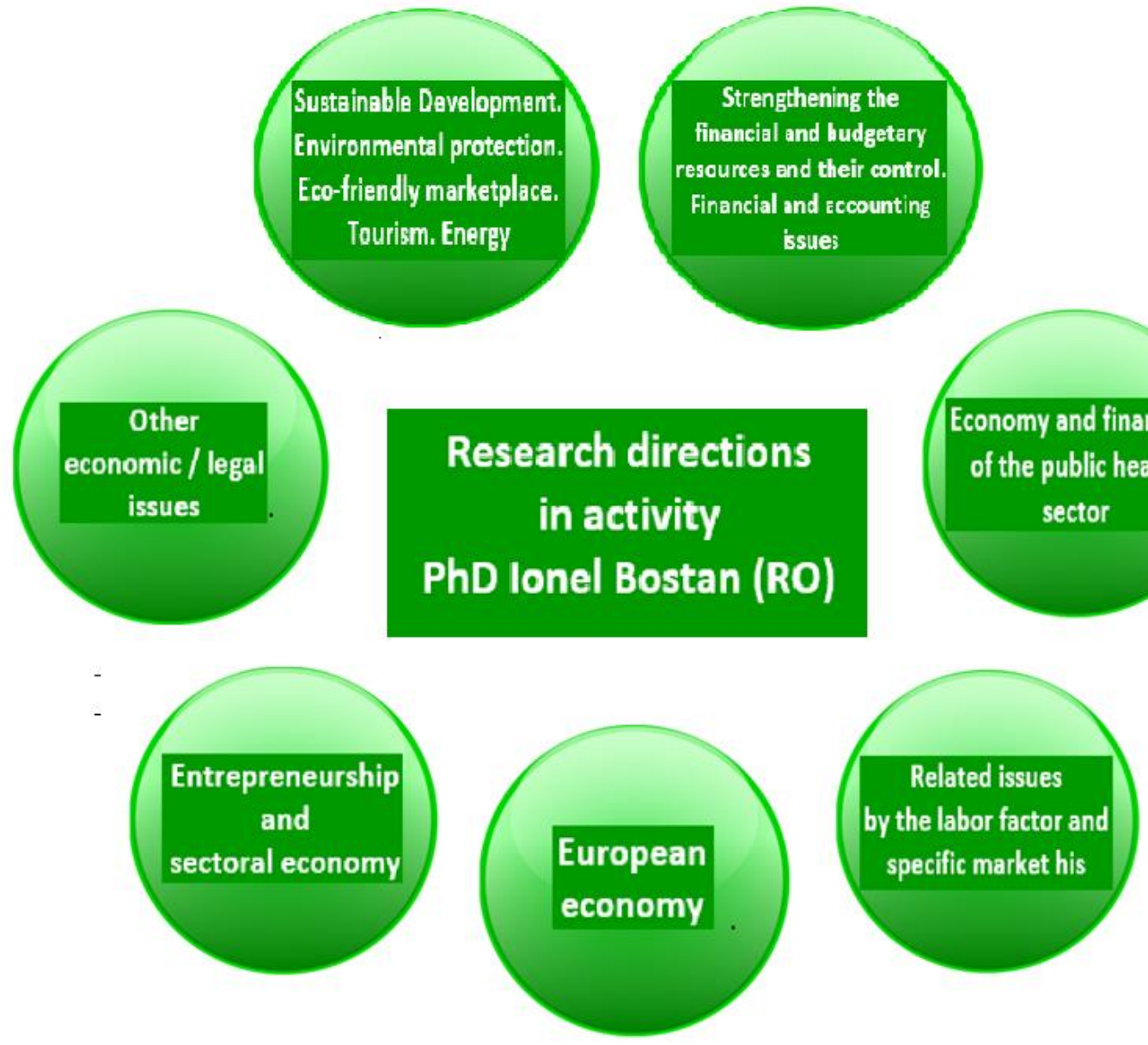

Figure 2: Systematization of economic research (lworks by author Ionel Bostan) aimed at identifying solutions for trivalent durability

issue related to the subject - trivalent durability: economic, social and environmental factors (Figure 2). For starters, we note that the author devotes a series of articles, published in several scientific journals indexed in international databases [22-38], addressing issues related to the
2. Trying to find solutions for trivalent durability: eeconomic (financial), social, and environmental

Given the importance of the topic we have set out in the title of this article, we mention that several Romanian researchers have had important concerns in this regard [421]. They approach a large number of components that make up the field in question. These approaches are economically feasible and partly juridical. We note, however, that in a series of scientific papers the Roamnian researcher Ionel Bostan comes in addition to addressing the financial
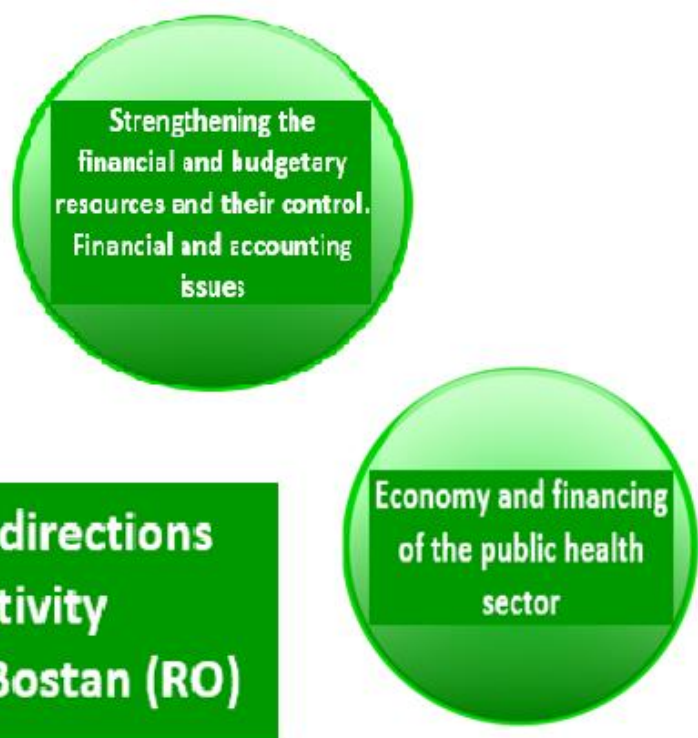

in activity

Bostan (RO) 
improvements in sustainable development strongly depends on the level of financial resources allocated, but the importance of specific accountability, prevention and control is also highlighted. On this latter aspect, the author claims that „Both public and non-domestic public audits are significantly different from public financial control (...)by the fact that the place of coercion and punishment of the law is taken by counseling, materialized in the recommendations provided to managers / authorizing budget appropriations. Otherwise, the main way the audit adds value to the managerial process is the issuing of recommendations, having the role of correcting the established dysfunctions, but also to solve their causes, aiming to prevent them in the future. So in assessing the performance of audit activities we will have less to do with quantitative indicators reflecting fines, confiscations, damages etc." [39]. Strengthening financial and budgetary resources and financial-accounting issues is the subject of debate in over thirty articles [40-73]. As pointed out by author, in its studies on convergentbidirectional legislative mobilization (anti-crisis and pro-sustainable development), the fact that „sustainable development is a general EU goal stipulated in the Treaty and which governs all EU policies and activities, which aims to promote a dynamic economy", is a serious reason for its multidisciplinary approach. That's why they found their treatment the issue of ensuring budgetary resources for biodiversity conservation and legislative solutions on securing funding for agricultural policy and rural development. It was not avoided the topic related to regulatory way at national level training and resource allocation intended to finance environmental projects and programs or a much more complicated issue regarding the economy and financing of the public health sector [74-81]. That's because „Promoting good public health in a fair manner and improving protection against health threats" is an objective of the European Sustainable Development Strategy, adopted at European Union level, at the European Council in Gothenburg, from June 2001. Thereforth, in prestigious scientific journals papers have been published on budgeting issues fighting serious diseases (cancer, TB etc.), bringing into discussion the "Berlin Declaration". Problems related to the work factor and its specific market [8286] could not be bypassed, especially that "People are at the heart of sustainable development concerns. They have the right to a healthy and productive life, in harmony with nature" [87]. Finally, tangential to the issues of sustainability and environmental protection, the author also debates themes of the European Economy [88-91], entrepreneurship and sectoral economy [92-96], but also other economic / legal issues [97-115]. What emerges from the study of these works is that obtaining resources to finance measures to achieve sustainable development objectives is difficult to achieve, even after the outbreak of European economies in the last global crisis. Otherwise, „identifying additional sources of funding for projects and extensive programs, particularly in the fields of infrastructure, energy, environmental protection, food safety, education, health and social services" is a major direction of action of The National Strategy for Sustainable Development of Romania.

\section{Conclusion}

Problems deriving from international, European and national strategies regarding natural resources and sustainable development deserves to be fully part of the scientific concerns of as many researchers as possible. In this article, we considered the creation of the Romanian researchers, especially of Professor Ionel Bostan, who work at universities in Iasi and Suceava (RO). What has emerged is that he tackles the issue of sustainable development and environmental protection, from interdisciplinary 


\section{References}

[1]. Comisia Mondiala pentru Mediu si Dezvoltare (2015). Retrieved from: http://success-romania.ro/economiesociala/ce-este-dezvoltarea-durabil-.htm

[2]. INFOGRAFIC (2017). Retrieved from: https://www.euractiv.ro/we-develop/ce-reprezinta-cele-17-obiective-dedezvoltare-durabila-odd-incluse-pe-agenda-2030-6402

[3]. MAE (2017). Teme globale. Retrieved from: https://www.mae.ro/node/35919

[4]. Albu, L. (2006). Analize privind factorii dezvoltării durabile pe termen foarte lung, Editura Academia Română: Institutul Național de Cercetări Economice, București.

[5]. Badea, A.; Voda, I. (2006). Dezvoltare energetica durabila. Seria : Politici, Strategii, Dezvoltare, Ed. Agir, Bucuresti.

[6]. Caracota, D.; Constantin, R. (2004). Dimensiuni contemporane ale dezvoltării durabile şi competitive. Idei și experiențe istorice; Editura ASE, București.

[7]. David, O. (2009). Dezvoltare economică și ecologie: elemente de legătură între acestea, Editura Universității "Petrol-Gaze", Ploiești.

[8]. Dinga, E.; Ionescu, C., Pădurean, E.; Băltărețu, C.; Leonida, I. (2011). Sustenabilitatea economică prin politici de ajustare în contextul globalizării. Editura Academiei, București.

[9]. Dobrescu, E.; Albu, L.L. (2005). Dezvoltarea durabilă în România. Modele şi scenarii pe termen mediu şi lung. Editura Expert, București.

[10]. Ivanoiu, M.; Sandu, V. (2005). Dezvoltare durabila, Ed. Universitatea Transilvania, Brașov.

[11]. Mihai, C.; Borza, M. (2009). Dimensiuni ale dezvoltarii durabile in Romania, Ed. Universitatea "Alexandru Ioan Cuza", Iasi.

[12]. Otiman, I.P. (2005). Dezvoltarea rurală durabilă a României în contextul integrării europene (I). Comunicare susținută la Academia Română, București. Retrieved from: www.acad.ro/com2005/pv1031/Otiman.doc

[13]. Pădurean, E.; Dinga, E.; Leonida, I. (2014). Fiscalitatea și dezvoltarea economică sustenabilă. Analele ASEM, ediția a XII-a, Nr. 1, pp. 212-215. Retrieved from: http://irek.ase.md/xmlui/bitstream/handle/123456789/112/Padureanu_E-Dinga_ELeonida_I.pdf?sequence $=18$ is Allowed $=\mathrm{y}$

[14]. Platon, V. (2004). Finanțarea activităților de protecție a mediului. Între teorie şi practică. Editura Economică, Bucureşti.

[15]. Pohoață, I. (2008). Strategii şi politici europene de dezvoltare durabilă. Editura Universității „Al. I. Cuza”, Iași.

[16]. Pohoață, I. (2003). Filosofia economică şi politica dezvoltării durabile. Editura Economică, Bucureşti.

[17]. Rusu, T. (2008), Bazele conceptului de dezvoltare durabilă, Editura U.T.Press, Cluj-Napoca.

[18]. Stoian, A. (2013). Sustenabilitate fiscală. Ajustări fiscale. Calitatea finanțelor publice. Retrieved from: http://www.ase.ro/upcpr/profesori/758/Seminar\%204_FPOP.pdf

[19]. Teodoroiu, S.M. (2009). Dreptul mediului și dezvoltării durabile. Editura Universul Juridic, București.

[20]. Toma, S.; Mereuță, D. (2004). Development of the environmental statistical system in România. INSSE Conference: Compliance of Romanian statistics with European statistical system, 13-14 May, Tulcea. Retrieved from: http:/ / www.insse.ro/cms/files/evenimente/Tulcea/romana/abstracț̦TomațRO.pdf

[21]. Vuță, M. (2004). Politici şi strategii financiare de protecție a mediului. Editura ASE, Bucureşti.

[22]. Bostan, I. (2015). Promotion and Support of the Natural Capital: Research on Ensuring the Financial Resources for the Conservation of Biodiversity (CBD) in the Romanian Space. Int. J. Environ. Res., 9(2):761-768, Spring. Retrieved from: https://ijer.ut.ac.ir/article_950_6c093af40d746203a574f2d4ba763744.pdf

[23]. Pohoață, I. Bostan, I.; Prelipcean, G.; Druguș, D.; Morariu, A.; Bunget, O. (2014). Equity, intra/inter-generation equalization and profit, in the context of the right to a healthy life and a clean environment. Rev. Rom. Bio. 12 (2), 58-69.

[24]. Roman, T.; Bostan, I.; Manolică, A.; Mitrica, I. (2015). Profile of Green Consumers in Romania in Light of Sustainability Challenges and Opportunities. Sustainability 7 (6), 6394-6411.

[25]. Bostan, I.; Burciu, A.; Condrea, P. (2010). Trends of the communitarian cohesion policies and advertising for eco-investments. Environ Eng Manag J, 9(6):847-851.

[26]. Bostan, I. (2016). Pro sustainable development: The influence of the law of entropy on economic systems. Environ Eng Manag J, 15 (11), 2429-2432.

[27]. Bostan, I.; Burciu, A.; Condrea, P.; Durac, G. (2009). Involvement of legal responsibility for severe acts of pollution and noncompliance. Environ Eng Manage J, Vol. 8, Issue: 3, Pages: 469-473.

[28]. Condrea, P.; Bostan, I. (2008). Environmental issues from an economic perspective. Environ Eng Manage J, Vol. 7, Issue: 6, Pages: 843-849.

[29]. Burciu, A.; Bostan, I.; Condrea, P.; Grosu, V. (2010). Financing the environmental policies in the communitarian space. Environ Eng Manag J, 9(9): 1179-1185.

[30]. Bostan, I.; Grosu, V.; Hlaciuc, E.; Mates, D.; Burciu, D.; Socoliuc, M.; Bunget, O. (2013). The environmental audit (EA) and the environmental balance sheet (EBS) in Romania. Journal of Food, Agriculture \& Environment $11(3 \& 4), 2587-2592$.

[31]. Bostan, I. (2016). An analysis of the "bio" / "eco" products market, referring to the EU and Romania. CES Working Papers 1 (8), 33-44.

[32]. Bostan, I.; Clipa, F.; Clipa, R.I. (2018). Is Romania a Sustainable Developed Country? An Analysis of Ecological Footprint $(\mathrm{EF})$ in Correlation with Human Development Index (HDI). Logos Universality Mentality Education Novelty: Economics \& Administrative Journal, Volume 3, Issue 1, Pages 5-14.

[33]. Pohoață, I.; Socoliuc, O.; Bostan, I. (2013). The Economic Impact Of Religious Tourism On The North East Region Of Romania. European Journal of Science and Theology 9 (2), 195-204.

[34]. Roman, T.; Lazar, C.; Manolica, A.; Bostan, I. (2016). The current trends and opportunities in the industry of medical tourism. Journal of tourism - studies and research in tourism 22, 58-63.

[35]. Condrea, P.; Bostan, I. (2017). The Consolidation of Romania's Energy Security Against the Background of the Euro-Atlantic Opening. PERFORM Publishing House 1, 187-200. 
[36]. Bostan, I. (2017). Concepts and Legal Grounds Regarding Renewable Energy Sources in the Context of Sustainable Development. PERFORM Publishing House 1, 119-129.

[37]. Maxim, A.; Mihai, C.; Apostoaie, C.M.; Popescu, C.; Istrate, C.; Bostan, I. (2016). Implications and measurement of energy poverty across the European Union. Sustainability, 8 (5), 483, doi:10.3390/su8050483

[38]. Iatco, C.; Bostan, I.; Lazar, C.; Burciu, A. (2013). Reconsidering economic coal resources in drafting energy strategies. The case of Romania. Environ Eng Manag J, 12(10): 2025-2030.

[39]. Bostan I.; Dascălu E.D. (2016). Strengthening the Sustainability of Public Finances by means of Financial Law focused on exercise Control and Audit activity. Ecoforum, Vol. 5, Issue 1(8), pp. 387-393.

[40]. Bostan, I. (2015). Towards a law of sustainable fiscal resources. CES Working Papers 7 (4), 851-863.

[41]. Bostan, I. (2016). Leveraging Sustainability as Budgetary resources through Financial Law Instruments. Annals "Constantin Brâncuși" University/ Economy Series, 33-42.

[42]. Bostan, I. (2015). The institution of legislative delegation in the fields of economics and finance. An overview of the timeframe 2010-2014. CES Working Papers 7 (1), 31-41.

[43]. Bostan, I. (2008). Drept financiar. Iaşi: Tehnopress.

[44]. Bostan, I.; Morariu, A.; Costea, I.M. (2006). Drept financiar public. Cluj: Dacia.

[45]. Bostan, I. (2010). Impactul sistemului financiar-fiscal asupra derulării schimburilor comerciale internaționale. Iaşi: Tipo Moldova.

[46]. Bostan, I. (2007). Drept financiar comunitar. Iaşi: Tipo Moldova.

[47]. Bostan, I. (2010). Drept bugetar european. Iaşi: Tipo Moldova.

[48]. Bostan, I. (2016). Considerations on insufficient legal regulation of special allocations made by the central executive authority. Journal of Public Administration, Finance and Law 9 (1), 119-124.

[49]. Bostan, I.; Nicula, C. (2017). Interventions on the legal framework of financial-budgetary reasons of national defense. The $19^{\text {rd }}$ International conference..., pp.49-56, DOI:10.19062/2247-3173.2017.19.2.7, Braşov, May 25 - 27. Retrieved from: http://www.afahc.ro/ro/afases/2017/7-M\&H-BostanIonel,NiculaVasileCosmin.pdf

[50]. Bostan, I. (2016). The legal regulation of the substitution of the budgetary credit release authority in exceptional conditions. Broad Research in Accounting, Negotiation, and Distribution 1 (1), 38-41.

[51]. Bostan, I.; Popescu, C.; Istrate, C.; Robu, I.B.; Hurjui, I. (2017). The impact of taxation of the domestic economic transactions on the VAT collection through electronic fiscal devices. Amfiteatru Economic 19 (45), 581-594.

[52]. Bostan, I. (2017). Practici recente în reglementarea juridică a exonerării de la plată a unor obligații bugetare/fiscale. Acta Universitatis George Bacovia (Juridica) 6 (1), 227-248.

[53]. Bostan, I. (2016). Changes and additions to the Tax Code: possible effects of reducing the Value Added Tax (VAT) rate to certain categories of benefits. Acta Universitatis George Bacovia. Juridica, Vol. 5, Issue 2, pp. 581-590. Retrieved from: https://www.ceeol.com/search/article-detail?id=475466

[54]. Asalos, N.; Hlaciuc, E.; Bostan, I.; Roman, T.; Mates, D.; Manolică, A. (2016). Mining remittances corresponding to metalliferous ores: regulation and budget impact. Metalurgija 55 (2), 278-280.

[55]. Bostan, I.; Radu, P. (2003). Controlul financiar și auditul intern la instituțiile publice. Iaşi: Sedcom Libris.

[56]. Bostan, I. (2000). Controlul financiar. Iaşi: Polirom.

[57]. Bostan, I. (2017). Adapting the Legal Framework of the Financial-Fiscal Investigations to Current Requirement. Law \& Society: Public Law - Tax eJournal 2 (103), 8.

[58]. Bostan, I.; Lazar, C.; Chihai, B. (2017). The legal regime applicable to financial audit in Army Units. The conference is organised under the auspices of the Management Academic Society in Romania, June 15 - 17, 2017, Sibiu, DOI:10.1515/kbo-2017-0083. from: https: / /www.degruyter.com/downloadpdf/j/kbo.2017.23.issue-2/kbo-2017-0083/kbo-2017-0083.pdf

[59]. Bostan, I. (2007). Investigații financiare: control extern-inspecție fiscală-expertiză contabilă. Iaşi: Tipo Moldova.

[60]. Bostan, I. (2005). Guidelines in the audit of Risk assessment. Comunicare susținută cu ocazia Conferinței, Probleme actuale ale situației ale situaiei social-economice a Republicii Moldova, organizată de Facultatea de Ştiințe Economice a Universității de Stat, Publication date: 2005/11/26, Vol.1, Pages 215, Publisher: USM Chisinau. Retrieved https://scholar.google.com/scholar?hl=en\&as_sdt=0,58scluster=14683141737133830369

[61]. Bostan, I. (2014). Juridical tools of Governmental nature used to mitigate various difficulties of the Financial and Budgetary System. Annals of the Alexandru Ioan Cuza University-Economics 61 (2), 133-148.

[62]. Bostan, I. (2010). Controlul financiar al afacerilor. Bucuresti: Universul Juridic.

[63]. Bostan, I. (2003). Controlul fiscal. Iași: Polirom.

[64]. Bostan, I. (2005). Company control implementation. Tehnologii moderne, calitate, restructurare (TMCR), Universitatea Tehnică a Moldovei, Chișinău, 19-21 Mai, pp. 305-308.

[65]. Grosu, V.; Bostan, I. (2010). IAS/IFRS Standards for SMES and the impact on the Romanian accounting system. International Journal of Academic Research, Vol. 2, No. 4, pp. 323-328. Retrieved from: http:/ /www.ijar.lit.az/pdf/6/2010\%284-41\%29.pdf

[66]. Bostan, I. (2010). Proceduri privind auditul public financiar și al performanței. Iaşi: Tipo Moldova.

[67]. Bostan, I. (2010). Auditul public extern. Bucuresti: Universul Juridic.

[68]. Bostan, I.; Grosu, V. (2009). Limits on legislative harmonization financial accounting. Proceedings, vol. I, The $33^{\text {rd }}$ the American Romanian Academy of Arts and Sciences (ARA) Congress "Modernism and Progress in Arts and Sciences", Universitatea Alma Mater din Sibiu, 2 - 7 Iunie 2009, Edited by Ecole of Polytechnique de Montreal, Polytechnic International Press Montreal, Quebec, pp. 250-253.

[69]. Bostan, I.; Grosu, V. (2011). Contribution of balance scorecard model in efficiency of managerial control. Romanian Journal of Economic Forecasting 14 (3), 178-199.

[70]. Costuleanu, C.; Bostan, I.; Horomnea, E.; Costuleanu, M.; Codreanu, C. (2011). Limitarea răspunderii civile în sfera auditării afacerilor, Economie teoretică și aplicată 18 (9), 562.

[71]. Clipa, F.; Bostan, I.; Clipa, R. (2016). Financial audit as a manifestation of institutional entrepreneurship. Knowledge Horizons - Economics 8 (3), 33-37.

[72]. Bostan, I.; Mates, D.; Grosu, V.; Socoliuc, M. (2008). Implications of fiscality over accounting in agriculture. Al 7-lea Simpozion Internațional "Perspective Ale Agriculturii Mileniului III", Organizat de Universitatea de Ştiințe Agricole si Medicină Veterinară Cluj-Napoca 2-4 Octombrie, 2008, in Bulletin of University of Agricultural Sciences Cluj-Napoca. Horticulture, Economics And Management Miscellaneous, 65(2):432.

[73]. Mates, D.; Bostan, I. (2010). Contabilitate fianciară conformă cu Directiva a IV-a a Comunității Economice Europene. Arad: Gutenberg Univers.

[74]. Voda, A.I.; Bostan, I. (2018). Public Health Care Financing and the Costs of Cancer Care: A Cross-National Analysis. Cancers 10 (4), 117. 
[75]. Bostan, I. (2016). Investigating the effectiveness of programs on health financing based on audit procedures. Iranian Journal of Public Health, Vol. 45, No. 8, Aug, pp. 1074-1079.

[76]. Hurjui, I.; Bostan, I.; Hurjui, M.C. (2016). Health care hazards associated with the trade policy on import/export of medicines in Romania. Rom J Leg Med (1), 78-79, DOI:10.4323/rjlm.2016.78

[77]. Hurjui, I.; Bostan, I. (2015). Reconfiguration of anti-TB (MDR and XDR) budgetary allocations, in the context of following "Berlin Declaration". Rom J Leg Med 23(4):296-299, DOI:10.4323/rjlm.2015.296

[78]. Hurjui, I.; Pete, S.; Bostan, I. (2016). Spatial distribution and the prevalence of speech disorders in the provinces of Iran. Journal of medicine and life 9 (1), 56.

[79]. Bostan, I.; Grosu, V. (2010). Economical and managerial influences in the public health systems. Rev Rom Bio, 8(2):97-103.

[80]. Tinică, G.; Bostan, I.; Grosu, V. (2013). Corelații privind creşterea economică şi evoluția costurilor aferente maladiilor cronice. Revista Română de Bioetică 8 (3), 15-24.

[81]. Tinică, G.; Bostan, I.; Grosu, V. (2008). The dynamics of public expenses in healthcare and demographic evolution in Italy and Romania. Revista Romana de Bioetica 6 (3), 56-63.

[82]. Bostan, I. (1999). Recompensarea factorului muncă. Iaşi: Media Tech.

[83]. Bostan, I. (2005). Managementul recompensei. Suceava: Editura Universității "Ştefan cel Mare".

[84]. Bostan, I.; Grosu, V. (2010). The social effects of the current economic crisis on the European Union labour market. Revista de Cercetare si Interventie Sociala, 31:7-21.

[85]. Bostan, I.; Popescu, C.C.; Dascalu, E.D.; Firtescu, B. (2016). The European Union cohesion policy and external migration in Romania. Multistage analysis. Rev. Cerc. Interv. Soc., Vol. 54, 96-114.

[86]. Bostan, I.; Istrtate, C.; Popescu, C.; Robu, B.I.; Costica, M.; Firtescu, N.B. (2016). Evolutions on the Labour Market in the European Chemical Sector. Rev. Rom. Chem. 67 (6), 1200-1202.

[87]. Success.Ro (2017). Economie sociala. Ce este dezvoltarea durabilă? Retrieved from: http://successromania.ro/economie-sociala/ce-este-dezvoltarea-durabil-.htm

[88]. Bostan, I.; Firtescu, B.; Toderascu, C. (2018). Exchange Rate Effects on International Commercial Trade Competitiveness. Journal of Risk and Financial Management, Analysis of Global Financial Markets, 11(2), 19; doi:10.3390/jrfm11020019

[89]. Bostan, I.; Năstase, C.; Druguș, D.; Morariu, A.; Bunget, O. (2014). Decrease the scourge of malnutrition in SubSaharan Africa through the implementation of EU financial instruments. Advances in Environ Sciences, Develop and Chem, Proceedings of the 2014 International Conference on Energy, Environment, Development and Economics (EEDS 2014 - Proceedings $®)$, Santorini Island, Greece, July 17-21, 2014, pp.454-459. Retrieved from: http://inase.org/library/2014/santorini/bypaper/ENVIR/ENVIR-69.pdf

[90]. Bostan, I.; Burciu, A.; Grosu, V. (2010). The consumerism and consumer protection policies in the European Community. Theoretical and Applied Economics no. 4, pp. 17-32.

[91]. Clipa, R.I.; Bostan, I.; Clipa, F. (2018). Efficiency Versus Equality In Regional Development Policy: The Case Of Romania. European Journal of Law and Public Administration 4 (1), 55-67.

[92]. Anton, S.G.; Bostan, I. (2017). The Role of Access to Finance in Explaining Cross-National Variation in Entrepreneurial Activity: A Panel Data Approach. Sustainability 9 (11), 1947.

[93]. Popescu, C.C.; Bostan, I.; Robu, I.B.; Maxim, A.; Diaconu, L. (2016). An Analysis of the Determinants of Entrepreneurial Intentions among Students: A Romanian Case Study. Sustainability 8 (8), 771, doi: $10.3390 /$ su8080771

[94]. Bostan, I.; Onofrei, M. (2012). The economic analysis of the evolution of Romanian ferrous metallurgy. Metalurgija 51 (4), 548-550.

[95]. Morariu, A.; Bostan, I. (2012). Trends in personnel and productivity associated with the steel industry in the Romanian economy. Metalurgija 51 (4), 551-554.

[96]. Bostan, I. (2012). The balanced scorecard (BSC) implications on the increase of public companies performance. African Journal of Business Management 6 (22), 6465.

[97]. Bostan, I.; Roman, T.; Manolica, A.; Bighiu, C. (2015). Investigating the correlation between personal values and overall satisfaction for consumers of higher education services and assessing the managerial implications. Revista de cercetare si interventie sociala 50, 66-79.

[98]. Bostan, I. (2015). The jurisdiction of financial macro-risks management. Annals. Economic Science Series, Vol. XXI, pp. 29-32, TIBISCUS University of Timişoara. Retrieved from: http://fse.tibiscus.ro/anale/anale2015.htm

[99]. Bostan, I. (2015). Legislative measures regarding the Romanian capital market in support of the transition from frontier market to emerging market. Annals. Economic Science Series, Vol. XXI, pp. 24-28, TIBISCUS University of Timişoara, Faculty of Economics. Retrieved from: http://fse.tibiscus.ro/anale/anale-2015.htm

[100]. Bostan, I. (2016). International trade of Romania in the context of its low economic potential. CES Working Papers 8 (4), 611-624.

[101]. Clipa, R.I.; Bostan, I.; Clipa, F.; Popescu, I. (2018). A Socio-Historical Excursus in the Approach of Institutionalism. Logos Universality Mentality Education Novelty: Economics \& Administrative Journal, Volume 3, Issue 1, Pages 15-23.

[102]. Clipa, R.; Bostan, I.; Popescu, I.; Clipa, F. (2016). Approaches to institutional quality and cyclicity of macroeconomic policies. Knowledge Horizons - Economics 8 (3), 50-54.

[103]. Popescu, C.C.; Bostan, I. (2016). Gold coinage. Case study: Romania and Republic of Moldova. Ecoforum Journal 5 (2(9)), 236-240.

[104]. Bostan, I.; Stoica, A. (2016). Exceptions to the principle of the binding power of contract effects on the relationships between the contracting parties under the New Civil Code. Acta Universitatis George Bacovia. Juridica 5 (1), 277-288.

[105]. Bostan, I.; Onofrei, M.; Popescu, C.C.; Lupu, D.; Firtescu, B. (2018). Efficiency and Corruption in Local Counties: Evidence from Romania. Lex Localis - Journal of Local Self-Government. Vol. 16, No. 1, pp. 215 229.

[106]. Bostan, I.; Pohoata, I.; Lazar, C. (2013). State control over commercial transactions with goods from precious metals. Metalurgija 52 (4), 553-556.

[107]. Stoica, A.; Lazar, C.; Bostan, I. (2016). The specificity of court judgments in cases appealed to the HCCJ with military from the navy. A doua editie a Conferintei Internationale SEA - CONF 2016, in Scientific Bulletin, Vol. XIX(1), pp.112-118, Edited by "Mircea cel Batran" Naval Academy Press (RO), DOI:10.21279/1454-864X-16I1-019. Retrieved from: http://oaji.net/articles/2016/3207-1468300415.pdf

[108]. Stoica, A.; Bostan, I. (2015). The relative conditions for the valid conclusion of a contract, under the New Civil Code. Acta Universitatis George Bacovia. Juridica 4 (2), 511-530. 
[109]. Stoica, A.; Bostan, I. (2015). Analysis of the New Civil Code provisions on the unjust enrichment. Acta Universitatis George Bacovia. Juridica, Vol. 4, Issue 1, pp. 273-281.

[110]. Bostan, I.; Stoica, A. (2015). The Management of Business in the New Civil Code. Acta Universitatis George Bacovia. Juridica - Vol. 4, Issue 1, pp. 227-240. Retrieved from: http://www.ugb.ro/Juridica/Issue_no7.pdf

[111]. Bostan, I.; Mates, D.; Hlaciuc, E.; Grosu, V.; Socoliuc, M.; Andronic, B.; Ciubotariu, M.; Apetri, A.; Morosan, Gh.; Mihalciuc, C. (2015). Exploitation of fishing resources in Suceava county: Profitability analysis (Rb/T) of specialized farms in a mountainous region. Arch Biol Sci, 67 (3), 909-920, DOI:10.2298/ABS140307052B

[112]. Bostan, I.; Pohoata, I. (2014). The BRICS-Evolutions and Trends as Seen From Neutral Economic Standpoints. Current Trends in Technology and Science 3 (5), 353-358.

[113]. Apetri, A.N.; Grosu, V.; Mates, D.; Bostan, I.; Socoliuc, M.; Hlaciuc, A.M. (2014). The Analysis Of Evolution And Financing Policies Of The Budget Deficit In Romania, In The Period 2007-2012. The USV Annals of Economics and Public Administration 14 (1 (19)), 177-186.

[114]. Pohoata, I.; Bostan, I.; Constantinescu, R. (2014). The rise towards excellence of social science in India: a 'Nobel'confirmation of the value of economics and further implications. CURRENT SCIENCE 106 (3), 368.

[115]. Moraru, M.; Bostan, I.; Grosu, V. (2014). Comparative study regarding financial statements of small and medium enterprises in Romania and Germany. Anale. Seria Stiinte Economice. Timisoara 20, 244. 